\title{
FIGURA CON INSTRUMENTO
}

\section{(Para una música de Wallace Stevens)}

Sergio Cueto

Universidad Nacional de Rosario

sergiojcueto@hotmail.com

Resumen: A partir del estudio del poema "Burghers Of Petty Death" ("Burgueses de nimia muerte") y su relación con otros textos del propio Stevens, se intenta pensar el carácter de la música stenvensiana en el espacio del invierno como lugar de devastación total.

Palabras clave: Música, Devastación, Vacío, Final.

\begin{abstract}
From the study of the poem "Burghers of Petty Death" and its relationship with other texts by Stevens himself, we try to think about the character of the Stevens's music in the space of the winter as a place of total devastation.
\end{abstract}

Keywords: Music, Devastation, Vacuum, Final. 


\section{Preludio}

A pesar de la complejidad del tema y la diversidad de sus variaciones, diremos que en la obra de Wallace Stevens la música está pensada según tres determinaciones fundamentales. En primer lugar, la música es y tiene que ser testimonio del presente, la voz y el sonido de su época, de su aquí y ahora. "Siéntate al piano, toca el presente", se le pide al poeta convertido en músico. Ahora bien, el presente se define por lo que se llama el desorden. Desorden en la naturaleza, en el mar y el sol, desorden en la ciudad, en esas súbitas nubes de rostros y de brazos y de gritos que invaden las calles a causa del dolor y el miedo. Sin embargo, dar testimonio del presente no significa tan sólo describir una situación, quiere decir, más prácticamente, aclarar el desorden y de ese modo absolverlo de sí, elevarlo al sosiego del orden, de un cierto orden, al menos. De allí que, en segundo lugar, la música sea y deba ser en cada caso y siempre un principio de orden, la simple puesta-enorden de lo que es. La música es el orden mismo. En tal sentido se dice que ella es un mundo y que es una con el mundo, que hace mundo y hace que el mundo esté en ella y ella sea el único mundo -el orden del mundo. Por supuesto que la voluntad de orden no obedece ni a la neurosis en el psiquismo ni al conservadurismo en la ideología del músico. Y ello porque el orden, la bella articulación que hace gozoso el presente, es el principio de la felicidad. El orden es la felicidad misma. ¡Cómo no iba la música a ser deseo de orden! Todo deseo es en el fondo deseo de orden. Por eso en tercer lugar la música es y tiene que ser siempre deseo, ella es la forma misma 
del deseo -su orden. Sólo secundariamente es la música sonido. La música es ante todo sentimiento, sensación, expresión del deseo en el cuerpo, el movimiento mismo del deseo atravesando el cuerpo. La música saca al oyente de sí y lo arrastra más allá de ella misma, el oyente quiere ir siempre más allá, pero ese más allá pasa por la música, no existe sino en el movimiento de la música. La música es deseo, y el deseo del oyente es siempre tan sólo deseo de música, deseo del deseo mismo.

Fuera de esas tres determinaciones no hay música, y la música no es nada fuera de esas tres determinaciones. Queda sin embargo todavía esa nada, esa nada ahí donde ya no hay nada, ni presente ni orden ni deseo, pero que se confunde con la pureza del hay mismo y en la que alguien habrá escuchado la proposición de otra música, una música que todavía espera interpretación.

\section{Ejemplo. Un poema}

Hay un poema de Stevens que sin dudas ubicaríamos entre aquéllos que Girri caracteriza como poemas sobre la vacuidad. El poema se titula "Burgueses de nimia muerte", y es el siguiente:

Estos dos junto al muro de piedra

Son una exigua parte de la muerte.

La hierba es verde todavía. 
Pero hay una muerte absoluta,

Devastadora, una muerte muy alta

Y honda, que cubre todas las superficies

Y colma la mente.

Aquí están los pequeños ciudadanos de la muerte, Un hombre y una mujer, dos hojas

Que se aferran al árbol

Antes de que el invierno se vuelva helado y negro.

Muy alta y honda,

Sin sentimiento alguno; un imperio de callada quietud

En el que una extenuada figura con instrumento

Propone una música vacía y última.

No pretenderemos comentar este poema. Dejaremos de lado la anécdota, la ocasión de su composición, las resonancias de su sentido, para atenernos tan sólo a lo que anuncia respecto del tema de la música tal como lo formulamos hace un momento.

\section{Última}

Ya es invierno, y sin embargo todavía están como en otoño en los árboles las hojas. Pocas. Una cae aquí, otra allá, algunas 
vacilan en las ramas. Muertas, resisten a la muerte. Hay un rumor de voces áfonas, un farfullar de voces muertas en el suelo y en los árboles. Pero cuando la última hoja haya caído, la muerte será absoluta y sin conmemoración, es decir, sin estela, sin monumento ni huella. Cuando la última hoja sea barrida por el viento, cuando ni siquiera el viento aúlle y la nieve apague el rumor sin voz de las hojas últimas, apenas quedará la huella de la ausencia de toda huella. Tras la caída de las hojas, hemos llegado al final, al final de la imaginación, sin duda, pero también al final del tiempo, ese momento en el que el presente se hace pasado y el pasado es el único presente. Pero es precisamente entonces, dice el poema, que viene la música. La música viene al final, después del final. La música empieza cuando todas las imágenes han pasado, cuando la imaginación misma ha alcanzado su fin. Por eso ella dice la ausencia, el vacío y el silencio de la imagen, y en ella todas las imágenes expresan una especie de silencio. Entonces, en el aire frío y transparente, se ilumina lo que Stevens llama "el llano sentido de las cosas". Nosotros decimos: lo obvio, el que es de lo que es. Es el único testimonio de la música, el último. "Lo que es es, y es lo que es", dice. Porque es última, porque ante ella ya no se abre nada más, el decir de la música es irreparable. La música es lo irreparable mismo. No sólo no se hallará reparo en la música, sino que la música expone a la intemperie sin reparo, a esa devastación que porque ha dejado atrás la muerte ya no tiene fin. Pero por lo mismo, porque es última, esa música no es un modo del deseo, parece más bien un sonido inmóvil, silencioso, quedo, una cosa del pasado, del presente como pasado, sin futuro. Habría deseo todavía si existiese un 
orden posible, o mejor, más simplemente, si en el presente faltara el orden. Pero a esa devastación mortal, a ese imperio de vano silencio que sucede al fin, aunque no le convenga el nombre de orden, de ningún modo puede dársele el de desorden. Se dirá que se trata de una ausencia de desorden que rechaza y ha rechazado de antemano toda idea de orden. Si es cierto, como dice Stevens, que hay un punto en el que orden y desorden son lo mismo y se anulan mutuamente, ese punto podemos encontrarlo no sólo en el sordo oleaje sin fin sino asimismo en el nevar callado y sin límites y en esta música vacía y última.

\section{Vacía}

El poema no pronuncia una sola vez la palabra 'nieve', y la hierba es verde todavía. Sin embargo, no puedo no leer en él un atardecer nevado, callado y quieto, en el que aparecerá después la desconocida figura con su instrumento. Diré que la música que el poema propone es la música de la nieve, una música de nieve. La música de la nieve es una suerte de canto llano, pero tal que la línea melódica, única, continua, se inmoviliza confundiéndose con el espacio, con el silencio. La nieve es en cierto modo el vacío de todas las cosas, el lugar en el que las cosas alcanzan su llano sentido, se exponen en su mero que es. En su obviedad, en la obviedad de su que es, cada cosa es contra un fondo de nada, casi apenas una huella de nada. Por eso la nada viene ahí con cada cosa como aquello que la cosa no es. En la música de la nieve escuchamos no sólo 
el silbar del viento, el rumor de unas pocas hojas, sino, dice Stevens, la nada que está ahí. El que escucha en la nieve escucha la nada en el silencio de la música. La música de la nieve es una música vacía. El vacío es el signo de lo que se llama lo real. "La realidad es un vacío", dice Stevens. Aquí y ahora, real es la devastación que lo cubre todo. La música de la nieve es como el severo recogimiento de la devastación. Por eso escuchamos en ella un desolado sosiego, el desolado sosiego de la más alta seriedad.

\section{Figura con instrumento}

Nada se nos dice de esa figura que aparece con su instrumento al final del poema. No sabemos si es hombre o mujer; suponemos que es humana, pero no tiene rostro. $\mathrm{Y}$ nada sabemos de su instrumento, flauta o guitarra, tambor o violonchelo. La figura resiste identidad, resiste el sentido, la inteligencia. Se nos pide aceptarla como parte de lo obvio, del sólido cierto: la devastada tarde invernal. De la figura sólo conocemos su carácter 'extenuado', wasted, dice Stevens. Wasted quiere decir arruinada, destruida, pero también abandonada, perdida, desperdiciada, y asimismo vana, inútil. Estrictamente devastada, la figura del músico figura la devastación en la que aparece y contra la que se recorta. Si se quisiese traducir según la etimología habría que elegir 'gastada' o 'desgastada'. La vasta devastación no sólo habrá gastado la figura casi hasta la desaparición, sino que constituye, se diría, su misma substancia, su mismo que es. La figura es una huella en el 
vacío. Ha pasado absolutamente, y es como pasada que se aparece, que viene a tocar la música del presente. O a proponerla, es decir, a postularla, a formular o exponer su idea. Sin embargo, el músico no tiene otro modo de proponer una música que ejecutándola. La devastada figura toca la música ideal de la devastación. Como si después de la devastación estuviese la música todavía. Una música vacía y última.

\section{Apéndice}

\section{Burghers Of Petty Death}

These two by the stone wall

Are a slight part of death.

The grass is still green.

But there is a total death,

A devastation, a death of great height

And depth, covering all surfaces,

Filling the mind.

These are the small townsmen of death,

A man and a woman, like two leaves

That keep clinging to a tree,

Before winter freezes and grows black-- 
Of great height and depth

Without any feeling, an imperium of quiet,

In which a wasted figure, with an instrument,

Propounds blank final music.

\section{Referencias Bibliográficas}

Stevens, W. (1954). Collected Poems. New York: Alfred A. Knopf

Girri， A. (1980). Stevens-Williams-Lowell/Poemas. Buenos Aires: Corregidor

Bloom, H. (1986). Los vasos rotos. México: FCE 